\title{
The Changing Nature of China's Higher Education
}

\author{
Linhan Chen ${ }^{1}$ \\ ${ }^{1}$ International College, Guangdong University of Foreign Studies, Guangzhou, China \\ Correspondence: Linhan Chen, International College, Guangdong University of Foreign Studies, Baiyun District, \\ Guangzhou City, 510420, Guangzhou, China. Tel: 86-020-3620-7150. E-mail: 199410395@oamail.gdufs.edu.cn
}

Received: February 26, 2013 Accepted: March 21, $2013 \quad$ Online Published: May 16, 2013

doi:10.5539/jel.v2n2p190 URL: http://dx.doi.org/10.5539/jel.v2n2p190

\begin{abstract}
This paper discusses the changing nature of China's higher education by turning to the changes that happened to China's higher education system brought about by implementing different government policies of higher education. The implementation of the policies, the restructuring of universities and independent colleges in 1952, the enrolling of workers, peasants and soldiers as college students, the turning from "elite" education to "mass" education and etc. results from the fact that China's higher education is by nature susceptible to changes, some of the changes being politically-driven, some economically-driven. Because of the changing nature, China's higher education is now a handy tool in the hands of those in power with which to realize their Utopian or egalitarian dreams and then a "powerhouse" generating knowledge as power pushing the country down the road to prosperity.
\end{abstract}

Keywords: China's higher education, reform, education system

\section{Introduction}

This paper is an effort to focus on the changing nature of China's higher education by addressing the changes in detail that happened to China's higher education system brought about by implementing different government policies of higher education. The paper elaborates on the policies, the restructuring of universities and independent colleges in 1952, the enrolling of workers, peasants and soldiers as college students, the turning from "elite" education to "mass" education and etc. that were adopted to meet the needs of the times. The ever-changing higher education of China's is sometimes politically-driven and sometimes it is economically-driven. Because of the changing nature, China's higher education is now a handy tool in the hands of those in power with which to realize their Utopian or egalitarian dreams and then a "powerhouse" generating knowledge as power pushing the country down the road to prosperity. On the whole China's higher education ever since 1949 is made up of two periods, the period before 1978 and that after 1978. In the first period the changes were meant to speed up the economic construction, to claim the proletarian dominance by reducing the disciplines of humanities and social sciences to a minimum and wiping out the church-sponsored private universities and to drive egalitarianism into the higher education system, bringing more opportunities to the children from working class families; in the second period, China's higher education system has experienced a drastic change in scope, in ideology, in structure and management, basically turning from the "elite" to the "mass" education and from the "home-bound" to the "internationally-oriented".

\section{Restructuring of Universities and Colleges in $\mathbf{1 9 5 2}$}

In 1952 a series of sensational events happened to the Chinese universities and independent colleges which were to bring about far-reaching effects upon China's higher education.

\subsection{Background}

When they came to power in 1949, the Chinese communists realized that they faced a politically and economically chaotic situation, as was especially true of the case with the country's higher education where, as Ma Xulun, minister of Ministry of Education said at the First National Conference on Higher Education in June 1950, anarchy was the order of the day, because every university or independent college was found in intellectual isolation, confined to the circle of its own educational ideas and practices. (Su, 1989, p. 9) Five years earlier, the scholar had given a summary of China's overall situation of higher education characterized by 1) concentration of higher education on big cities along or close to coastlines; 2) preference given to humanities, social sciences and law over engineering and pure sciences and 3) therefore, much too serious shortage of the disciplines of 
engineering, education, medicine, agriculture and forestry to meet the needs of the socialist construction. (Li, 2002, p. 72) According to the statistics released in 1947, of all the college undergraduates those majoring in engineering and sciences accounted for less than $17.8 \%$, compared with the share of $46 \%$ taken by the students of humanities and social sciences, politics, law and finance. For the Chinese government the situation had to be changed after the Chinese people freed themselves from the yoke of imperialism and started to go down the road of independently building socialism ( $\mathrm{Su}, 1989$, p. 13) Another form of chaos was to be found, as the communists viewed, in the fact that more than 100,000 intellectuals across the country were mostly senior faculty members who followed the English and American bourgeois ideas and upheld factionalism and individualism. Those lecturers and professors were hostile to the government's efforts to copy the Soviet style of higher education and to part with the western-style higher education. (Zhang, 2007, p. 90)

\subsection{Restructuring}

In July and November 1951 the Ministry of Education convened two meetings attended by the presidents of the country's agricultural colleges and polytechnic colleges respectively, which gave a start to the nation-wide restructuring of universities and colleges. In May 1952 the Ministry of Education showed explicitly the plan for the restructuring and the guidelines which consisted in training talented young people for the industrial construction, developing polytechnic colleges specializing in manufacturing, farming, medicine, teacher-training, politics and law, finance and economics, etc. The ministry demanded that there be no more than 4 universities for the teacher-training per administrative region composed of 3 or 4 provinces, and far more specialized polytechnic colleges and three-year colleges. ( $\mathrm{Li}, 2002$, p. 74) For that purpose polytechnic colleges of a university merged those of another and turned into new and independent polytechnic colleges while the colleges of liberal education covering history, education, linguistics, psychology, politics and those of finance and law were either cancelled or kept to a minimum in scale.

During the process of the restructuring some guidelines were noticeably adopted. The restructuring started firstly in Beijing and Tianjin Administrative Region where financial resources, faculty members were redeployed and disciplines of universities were re-set. Importance was attached to the restructuring of important or famous universities. Peking University, Qinghua University and Yenching University became a key part of the whole process because with a good job done there they would serve as a good example for others. (Zhang, 2007, p. 92) The Soviet higher education was shown as a model of what the Chinese universities and colleges had to learn from and align with. (Su, 1989, p. 13) The restructuring in the region started in July 1952 and ended two months later and in the year it was pushed ahead in three fourths of the country's universities and independent colleges, especially in such administrative regions as north China, northeast China and east China. (Li, 2002, p. 74)

\subsection{Effects}

Scholarly opinions have varied on what resulted from the restructuring of the country's universities and independent colleges in 1952 and the disagreement has been on in the academic world.

\subsubsection{Favorable Effects}

The scholars for the restructuring focus on the several points for supporting the advantages following the restructuring, although they are made fully aware of the problems that arose from the restructuring:

\section{1) Colleges Going on a Much Greater Scale}

Greater universities and independent colleges were built. The number of the college students rose from 700 in 1952 to 1172 in 1953 and that of the universities and colleges with a total of 10,000 students rose from 0 in 1952 to 13 in 1954, (Wu, 2001, p. 82) and the number of the institutions of higher education fell from 205 in 1949 to 181 in 1954, though. (Jiao and Li, 2000, p. 81) The building up of the greater colleges realized the economy of scale to have done away with the waste of financial and human resources and chaos in the structure of university disciplines. Prior to 1952 the universities and independent colleges specializing in engineering and technology all across the country had the capacity of admitting no more than 15,000 students, while after the restructuring the capacity doubled. The enrollment rate of the universities and independent colleges nation-wide rose by $8.9 \%$ in 1953. (Su, 1989, p. 14)

\section{2) More Specialized Disciplines Established}

Along with the restructuring the Soviet model of higher education was introduced and more specialized disciplines of engineering and technology were established which fueled a revolution in structure and content of higher education and promoted the combination of theory and practice and the cooperation between the universities or colleges and the industrial sectors. (Su, 1989, p. 13) With the restructuring pushed ahead 12 sectors of knowledge and technology such as iron and steel making, geology, metallurgy, conservancy of water 
resources and etc appeared in the university classrooms. (Li, 2002, p. 74) They were an introduction to a variety of university subjects such as the peaceful use of atomic energy, jet technologies, semi-conductor research and computer science, all of which met the needs of the country's socialist construction. (Wu, 2001, p. 82)

\section{3) More Balanced Coverage of Higher Education in the Country}

Historically, China's universities and colleges scattered in the east of the country or along the coastal areas. After the restructuring the number of universities and independent colleges in the inland rose from 87 in 1951 to 115 in 1957, covering the northeast, the southwest and the middle south of the country. (Wu, 2001, p. 82) Although the restructuring in 1952 didn't result in a dramatic rise of the number of universities or independent colleges and a reduction was even observable in Shanghai, Jiangsu and Guangdong, the restructuring paved the way for a steady growth in the western and northwestern parts of the country in the following years. Take Shanxi and Xinjiang, two northwestern autonomous region and province, for example. The numbers of universities and independent colleges rose to 13 and 5 there respectively in 1956. (Su, 1989, p. 15) All the efforts effectively improved the situation of little or no coverage of higher education in the north and westernmost parts of the country.

\subsubsection{Disastrous Effects}

Quite a lot of scholars have taken notice of some side effects from the restructuring and a few are diametrically opposed to it. They highlight the following several points:

\section{1) Disciplines of Liberal Education and Private Universities Weakened or Destroyed}

For many scholars the restructuring of the universities and independent colleges in 1952 was characterized by the determination of the communists who had recently come to power to put an end to the old educational system primarily by reducing and destroying the disciplines of liberal education and private universities that for them stunk with the bourgeois ideology and had links to the capitalist countries. The government was hard at work trying to do away with many good and reasonable elements of the old educational system such as the disciplines of law, finance, politics, sociology, psychology, news media, household management, theology and etc. The parts of liberal education were ignored on purposed because they were for the communists sectors of knowledge seriously tainted by the corrupt western ideology. (Wu, 2001, p. 82) In 1949 students majoring in humanities, finance and politics accounted for $10.2 \%, 16.6$ and $6.3 \%$ of all the college students, while in 1953 the numbers fell to $6.7 \%, 6.4 \%$ and $1.8 \%$ respectively. (Su, 1989, p. 15) The church-sponsored Yenching University was forced to close down in 1952, with all its colleges annexed by Beijing Normal University, Qinghua University, Tianjin University, and Peking University. (Zhang, 2011, p. 60) Somewhat the same thing happened to Fu Jen Catholic University in the same year. The cancelling of private institutions of higher education put an end to the tradition of citizens running their own universities and colleges besides adding greatly to the financial burden on the government. (Shen, 2008, p. 74)

2) Serious Brain Drain of Famous Scholars from First-class Universities

Accordingly, at the height of the restructuring of the universities and independent colleges there occurred a great reshuffling of faculty members in Chinese universities, as some of them had to be transferred to other universities or colleges to reinforce the human resources there and some had to go to the inland. As a result, some universities, Qinghua University being one among the rest, very well known at home and overseas, ceased to be comprehensive universities, while some others such as Peking University, Zhejiang University, Nanjing University, Sun Yat-san University and Wuhan University suffered great losses. (Li, 2002, p. 76) In Table 1 in the following are shown statistics concerning the drain of scientists from very well-known universities:

\section{3) Faculty Members Brainwashed}

In the process of the restructuring, the university faculty members were systematically brainwashed. In his article "Political Study of the Faculty Members of Peking University" carried on October 23rd, 1951, the president of the university said: "In accordance with the needs of the country, we must carry out the restructuring thoroughly, improve the college curriculum and methodology and to reach the targets we must of our own accord join the process of renewing our ideology". (Shen, 2002, p. 77) The Renewing the Ideology Drive was carried out in all Chinese universities and independent colleges in 1952 in order to uproot the reactionary ideology of the American and British capitalists, individualism, objectivism and factionalism. During the Renewing the Ideology Drive all the intellectuals were put in the "ideological bath" that took the form of political propaganda, moral encouragement, examination and purging. Up to the autumn of $1952,91 \%$ of the faculty members and $80 \%$ of the college undergraduates were "bathed". (Zhang, 2007, p. 91) The drive so much went home that every faculty member would feel like getting his or her amnesty when told that his or her performance was a "Satisfied". 
(Shen, 2002, p. 77) For many scholars one thing that followed was for sure the more or less loss of creative and critical thinking on the part of the faculty members of the Chinese universities and colleges.

Table 1. Distribution of Chinese scientists in institutions of higher education before and after restructuring (based on the formerly best universities and independent colleges)

\begin{tabular}{llllll}
\hline Institution & Before 1952 & Outgoing & Staying & Incoming & After 1952 \\
\hline Qinghua U. & 65 & 52 & 13 & 1 & 14 \\
Peking U. & 52 & 41 & 11 & 20 & 31 \\
Nanjing U. & 27 & 18 & 9 & 3 & 12 \\
Zhejiang U. & 26 & 24 & 2 & 0 & 2 \\
Peking Union Medical C. & 15 & 2 & 13 & 1 & 14 \\
Shanghai Jiaotong U. & 13 & 9 & 4 & 3 & 7 \\
Shanghai Medical C. & 10 & 3 & 7 & 0 & 7 \\
Sun Yat-san U. & 8 & 8 & 0 & 1 & 1 \\
Tianjin U. & 8 & 6 & 2 & 4 & 6 \\
Tongji U. & 8 & 6 & 2 & 0 & 2 \\
Nankai U. & 7 & 4 & 3 & 1 & 4 \\
Shandong U. & 6 & 5 & 1 & 1 & 2 \\
Lingnan U. & 6 & 6 & - & - & - \\
Chongqing U. (cancelled) & - & 5 & 4 & 1 & 2 \\
Wuhan U. & 5 & 3 & 2 & 0 & 2 \\
Jinling U. (cancelled) & 5 & 5 & - & - & - \\
Northern Jiaotong U. & 5 & 4 & 1 & 0 & 1 \\
\hline
\end{tabular}

Note. Figures listed above are adapted from Lives of Modern Chinese Scientists, Beijing: Science Publishing House, 1991-1994.

\section{College Students Born of Workers, Peasants and Soldiers}

In 1966 the so-called Great Cultural Revolution started under the guidance and maneuvering of Mao Zedong and the Cultural Revolution Commanding Group headed by the first deputy group leader, Jiang Qing, Mao's wife. Of the Cultural Revolution, China's education, especially higher education bore the main brunt in which, as Mao, Jiang and their comrades thought, there was a 17 -year-old dominance of the revisionist education and to which a fundamental change was inevitable. They closed down universities and independent colleges all over the country and they restored them four years later; they stopped enrolling students and they admitted workers, peasants and soldiers to universities and independent colleges as college students four years later. They may have been pressed to take the step, because on the one hand the Great Cultural Revolution claimed its significance in, among others, replacing institutional education with less institutional education by abolishing the elite education Mao called the 17-year-old revisionist education, making education accessible to masses of young people from workers' and peasants' families and on the other the middle school graduates who by 1970 had gone down to the countryside in four consecutive years to be reeducated by peasants would make qualified "Red Guards", successors to the revolutionary cause with knowledge arming them.

\subsection{Ideology and Reality}

\subsubsection{Speaking for Utopian and Democratic Higher Education}

The Chinese Communist Party has been said to feel attached especially to workers and peasants not only because the party itself allegedly represents their fundamental interests but also because workers and peasants contributed greatly to the victory of the Chinese revolution and would serve as a vital force in the socialist construction of a new China. (Luo, 2008, p. 106) Conceivably Mao and his comrades would have been happy if there had been a greater proportion of workers and peasants who were able to go to universities or independent colleges in the 
1950s. They were not, however, as one may find out when reading the speech delivered by Mao in 1957 at a meeting attended by the party heads of the provinces, municipalities and autonomous regions: As a survey conducted by Beijing Municipal Government shows, the students of the universities and independent colleges were mostly the sons and daughters of the landlords, the rich peasant class, the upper-middle peasants and the capitalists, while those from workers' families, from the families of poor and lower-middle peasants came up to less than 20\%. (Hai and Xiao, 2010, p. 32) The editorial of People's Daily dated on July 3rd, 1958 raised the proportion at a little over $30 \%$, which didn't comply with the nature of a socialist country, nor with the reality of a country where more than $80 \%$ of the population were workers and peasants. (Luo, 2008, p. 106)

\subsubsection{Giving Favored Treatment to Workers' and Peasants' Families}

In the first several years after the founding of the People's Republic of China the communists made the institutional education less institutional by requiring universities and independent colleges to lower standards for admitting workers and peasants to colleges. The worker-turned or peasant-turned government officials, for example, were able to go to college after a half year of preparatory training. (Zhang, 2007, p. 94) The recommendation for test-free admission was a short-cut to boosting the proportion of college students from workers' and peasants' families. On June 17, 1957 the Ministry of Education issued An Announcement of the Recommendation for the Test-free Admission Treatment to Graduates from Workers' and Peasants' Short-training Schools, Government Officials with the Working Class Background, Senior Government Officials and Excellent High School Graduates. In the same year the favored treatment resulted in a dramatic rise of the proportion of workers and peasants to $48.2 \%$ of all those given recommendation for test-free admission, compared with $36.3 \%$ in 1957 . In the next few years the government kept giving the favored treatment to all the groups of people above, exclusive of excellent high school graduates. According to the statistics released by Newsletter of the Enrolment in 1964 of the Institutions of Higher Education, 42,258 people got recommended for test-free admission, of whom 26,265 were admitted to universities and independent colleges. The students from workers' and peasants' families made up $90.72 \%$ of the whole, while those from the exploiting classes fell to $0.6 \%$. In 1964 the students enjoying the favored treatment came up to $17.9 \%$ of all the students enrolled. (Luo, 2008, p. 108)

\subsection{Time to Restore Universities and Colleges and Guiding Principles}

In 1966 the Great Cultural Revolution swept across the country vehemently so that universities, middle schools and primary schools ceased to operate, when nearly one million middle school graduates were by no means able to go to colleges. Up to 1970 it was already four years since middle school graduates were admitted to universities and independent colleges. Many military units entered the campus and occupied the campus grounds in the name of "borrowing" them for "preparing for war against the neighbor in the north. Mao Zedong knew the situation and was not satisfied with it because for him a revolution in education was necessary, but that didn't mean an end to universities and independent colleges. (Hai and Xiao, 2010, p. 32)

Mao Zedong, after reading "A Survey of the Training of Technical People by Shanghai Machine Tool Factory" published on July 21, 1968, commented on it, saying "We should have our universities, I mean poly-technical universities, but they should offer shorter programs. The education should be revolutionized, with the proletarian politics dominating everything...we should select from workers and peasants with work experience college students who spend years on campus learning and after graduation get back to work at the place from which they came. (Lu, 2012, p. 48) The survey was a product turned out under the dominance of the left extremist ideology, casting satires on the incompetence of the bourgeois intellectuals they showed when working at factories and exaggerating the ability of the working classes to "create miracles". The survey with the two functions reinforced Mao's thinking that the dominance by the bourgeois intellectuals should cease to be.

\subsection{Worker-Peasant-and-Soldier Students Appearing on Campus}

When it was coming to the year 1970, the tide of the Great Cultural Revolution was at a low ebb. Views were aired of restoring the enrollment of the universities and independent colleges. On the 27th of May the Committees of the Chinese Communist Party of Peking University and Qinghua University submitted to the Central Committee of the Chinese Communist Party and the State Council A Draft Proposal of Enrolling Students in Beijing University and Qinghua University, (Hai and Xiao, 2010, p. 33) showing a road map how to shorten the teaching program, how to run the universities and how to enroll students from among workers, peasants and soldiers. 


\subsubsection{Workers, Peasants and Soldiers Going to College}

Access to college was given to workers, poor and lower-middle peasants and soldiers who aged around 20 with the education above that of a junior middle school student, young government officials and those who did their jobs remarkably well in their companies and government organs, after the local Revolutionary Committee checked their political backgrounds and recommended them for admission to universities and independent college for a three-year program of learning. (Hai and Xiao, 2010, p. 33) A lot of workers, peasants and soldiers became the worker-peasant-and-soldier college students.

The level of education may perhaps be a matter of interest for many. Take Peking University for example. In 1970 a total of 2392 people was admitted to it, of whom 171 had the education that of a middle school student, 2142 of a junior middle school student and 79 of a primary school student. (Lu, 2012, p. 48) The recommendation practice was a bold step the government took in the history of modern Chinese education, but for many the government went much too far, practicing the principles of egalitarianism (Luo, 2008, p. 109) because they put a high value on the family political background and meanwhile ignored the academic competence of the worker-peasant-and-soldier students. As a result, the education of the worker-peasant-and-soldier students was never anything realized.

\subsubsection{Worker-Peasant-and-Soldier Students Living Their Lives on Campus}

The worker-peasant-and-soldier students lived a life fully politically-driven. They had some guiding principles to follow which were embodied by "I come, I rule and I rebuild the university by Mao Zedong Thought". (Hai and Xiao, 2010, p. 34) They would take part in the political activities covering setting up a branch of the Communist Party of China and a company for living a semi-military life, going out on a long march to factories, villages and army units to learn and to get trained, and they would also engage themselves in manual labor for building up national-defense works, such as making bricks and digging air-defense caves. In addition, the worker-peasant-and-soldier students were asked to go to the Cemetery for Revolutionary Martyrs to pay the tribute to those who had died for the revolutionary cause, to listen to poor old peasants recalling their painful experiences in the old days, to help compile the village history for the local people and, to watch the Exemplary Modern Peking Operas...The time for acquiring knowledge and skills was reduced to a minimum. (Lu, 2012, p. 52) Complaints were heard later among most of the worker-peasant-and-soldier students and the premier of the State Council intervened by arranging for the students to follow a more regular timeline of study. (Hai and Xiao, 2010, p. 33)

\section{Educational Reform Since 1978}

Since 1978 when the policy of the reform and opening-up to the outside world was carried out, many measures have been taken to develop the higher education such as expanding student enrolment. Its focus has been shifted from "elite" education starting in 1978 to "mass" education. And the higher education system has been reformed to meet the demands of economic development and socialist construction. In addition, great efforts have also been made to internationalize China's higher education.

\subsection{Student Enrolment under the Reform and Opening-Up to the Outside World Policy}

1978 was a year of historical significance when it comes to the student enrolment of China's higher education. In that year, the central government decided to focus its attention on economic development, implementing the reform and opening-up to the outside world policy which gave a great impetus to the reconstruction of the country's ideology in the first place, economy and education as well. Against the background, the reconstruction of China's higher education was brought to a high agenda. The reform was practiced in the enrolment of higher education. The enrollment policy enacted in the past ten years, the one by which students were selected mainly according to their family backgrounds and political beliefs saw a turning point. Thousands of young people attended the nation-wide college entrance examinations, but the enrolment rate was lower than 5 percent. According to the statistics, only 280,000 students, that is, 4 percent of the participants, were admitted to universities and independent colleges. China had been confronted with a great demand for resources in higher education. The change in the enrolment policy was a preliminary step for the development of higher education. People all regard the year of 1978 as a watershed of higher education in China.

The national conference on education convened on April 22, 1978 is regarded as the emblem of higher education reform in China. At the conference, Mr. Deng Xiaoping said that higher institutions were places where to train competent human capitals for socialist construction, which reserved some of Mao's idea (p. 3). He emphasized the important role of higher education in the development of China. Mr. Deng believed that science was the first powerhouse for improving the productivity and education could help achieve the target. Therefore, the college 
entrance examinations were resumed in late 1977. The first group of students was enrolled based on their academic scores in the spring of 1978, which was a very special thing because China's universities' intake normally happens in autumn. The time of the entrance examinations and enrollment indicated an urgent need for change in China's higher education.

\subsection{Higher Education System Reform}

\subsubsection{Reinstating Academic Degrees}

Since the first college entrance examinations, the Ministry of Education has kept improving the higher education system to meet the rising demands of the country's development. In order to cultivate more scientists and competent human capitals, a lot of measures have been taken, such as standardizing and unifying the examinations, increasing the number of subjects for the entrance examinations by which to select the best qualified students. (Hu \& Seifman, 1987, p. 32) In February 1980, academic degrees were reinstated with the support of the Standing Committee of the Fifth National People's Congress which showed China's determination to update Chinese academic criteria and to parallel its standards with international counterparts.

\subsubsection{Diversifying the Higher Education and Reforming Universities and Independent Colleges}

During the period, to provide more opportunities to people, the Ministry of Education introduced various forms of higher education such as part-time colleges, television and correspondence universities, short-term vocational colleges and self-study programs as supplements to higher education. As a result, the number of the institutions of higher education doubled. In May 1985, an important document on the reform of education system was issued, which was regarded as a milestone in accelerating the transformation of higher education in China and conveyed the principles and orientation of specific reforms. "The fundamental aim of restructuring education is to improve the quality of the nation and to produce as many skilled people as possible". (Tan, 1985, p. 6) Again during the period, there were a lot of innovative ideas, and exploratory reforms in higher education. For example, universities and independent colleges were given more autonomy, because they were granted powers to define teaching content and techniques. They were given the right to enroll enterprising and self-funded students, which was impossible before 1978. Although innovative ideas and exploratory reforms were displayed, great improvements were yet to be made. However, they did make preparation for later reforms in higher education.

\subsubsection{Merger of Universities and Independent Colleges in the Middle 1990s}

In February 1992, Deng Xiaoping paid a visit to South China, during which he proposed a series of theories and guiding principles for the further development of socialist construction with the Chinese characteristics. Building socialist market economy was derived, and higher education was overwhelmed with the opportunities of development. A reform of higher education has been gradually implemented since then. The merger of universities was carried out to pursue the further development of higher education. There were two driving impetus in merging universities. One was to create a group of world-class universities by merging some universities to the others and making the disciplines of new universities more comprehensive. The other one was to make the universities more efficient. (Qu, 2005, p. 152) In the process, 400 or so institutions experienced a great transformation through decentralization and amalgamation. (Li and Shen, 2003, p. 18) The merger of the universities made the following reform available. In 1995, Project 211 was introduced as a principal development strategy in the reform of higher education. About 100 universities were selected to improve their education quality, to promote scientific research, to upgrade management and to increase institutional efficiency as well.

\subsubsection{A Shift from "Elite" Education to "Mass" Education}

Although a lot of experiments and reforms had already been carried out, the scale of universities' enrolment failed to meet the needs of the economic development in the early 1990s. The late 1990s saw a dramatic growth of student enrolment and expansion of higher education in China which can be shown in Table 2:

Table 2. Institutions of higher education, student enrolment and growth rate, 1998-2011

\begin{tabular}{llllllll}
\hline Year & $\begin{array}{l}\text { No. of } \\
\text { Institutions }\end{array}$ & $\begin{array}{l}\text { Students } \\
\text { on Campus }\end{array}$ & $\begin{array}{l}\text { New } \\
\text { Enrolment }\end{array}$ & $\begin{array}{l}\text { Growth } \\
\text { Rate (\%) }\end{array}$ & $\begin{array}{l}\text { Graduates } \\
\text { on Campus }\end{array}$ & $\begin{array}{l}\text { New } \\
\text { Enrolment }\end{array}$ & $\begin{array}{l}\text { Growth } \\
\text { Rate (\%) }\end{array}$ \\
\hline 1998 & 1,022 & $3,408,700$ & $1,083,600$ & ---- & 198,885 & 72,508 & ---- \\
1999 & 1,942 & $7,189,100$ & $1,596,800$ & 47.36 & 233,500 & 92,200 & 27.15 \\
2000 & 1,813 & $9,097,300$ & $2,206,100$ & 38.16 & 301,200 & 128,500 & 39.37 \\
\hline
\end{tabular}




\begin{tabular}{llllllll}
\hline 2001 & 1,911 & $11,750,500$ & $2,682,800$ & 21.61 & 393,300 & 165,200 & 28.56 \\
2002 & 2,003 & $14,625,200$ & $3,205,000$ & 19.46 & 501,000 & 202,600 & 22.63 \\
2003 & 2,110 & $11,085,600$ & $3,821,700$ & 19.24 & 651,300 & 268,900 & 32.72 \\
2004 & 2,236 & $13,335,000$ & $4,473,400$ & 17.05 & 819,900 & 326,300 & 21.34 \\
2005 & 2,273 & $15,617,800$ & $5,044,600$ & 12.77 & 978,600 & 364,800 & 11.79 \\
2006 & 2,236 & $17,388,400$ & $5,460,500$ & 8.24 & $1,104,700$ & 397,900 & 9.07 \\
2007 & 2,321 & $18,849,000$ & $5,659,200$ & 3.63 & $1,195,000$ & 418,600 & 5.20 \\
2008 & 2,663 & $20,210,200$ & $6,076,600$ & 7.37 & $1,283,000$ & 446,400 & 6.64 \\
2009 & 2,689 & $21,446,600$ & $6,394,900$ & 5.24 & $1,404,900$ & 510,900 & 14.45 \\
2010 & 2,723 & $22,317,900$ & $6,617,600$ & 3.48 & $1,538,400$ & 538,200 & 5.33 \\
2011 & 2,762 & $23,085,100$ & $6,815,000$ & 2.98 & $1,645,800$ & 560,200 & 4.09 \\
\hline
\end{tabular}

Note. Figures From 1998 to 2011 are adapted from the annual National Educational Development Statistical Bulletin issued by the Ministry of (http://www.moe.gov.cn/publicfiles/business/htmlfiles/moe/moe_633/201208/141305.html)

China experienced significant changes in the structure of its higher education policy as witnessed by its shifting emphasis from an educational policy focused on the "elite" to the one underpinned by "mass" education as can be fully shown by reading the statistics listed above. The year of 1999 can be considered as the watershed between past and current educational policies with the expansion of student enrolment going on in a big way to meet the growing demands for highly skilled graduates required by a burgeoning Chinese economy. (Jin, 2005, $\mathrm{p}$. 313) The enrollment growth rates in 1999 and 2000 should have been boosted to $47.36 \%$ and $38.16 \%$ respectively for undergraduate students and to $27.15 \%$ and $39.37 \%$ for graduate students, something that really made history which shows that, besides there being ever-increasing demands for a qualified and educated workforce, by that time the overall strengths of China's were such that they put China in a position to perform deeds unheard of before. The enrolment expansion had three driving engines. The first one was that the government initially wanted to turn the elite into the mass education to achieve two goals, that is, providing more opportunities for people of college age to receive higher education and realizing equality in education. (Wong and $\mathrm{Lu}, 2008$, p. 110) The second one was that China's burgeoning economy required a rapid development of higher education. Over the past two decades the tremendous economic development in China has stimulated reforms in higher education and brought about some remarkable changes. (Duan, 2003, p. 1) The third one consisted in a response to the market demand. China has a very large population and it needs a much larger scale of higher education. Kinglun Ngok (2008) described the change as resulting from the fact:

All colleges and universities in China had been under direct state control, so that they were run, funded, and managed by the government. Such a system led to a narrow range of educational resources and stifled the development of higher education. (p. 550)

\subsection{Internationalization of China's Higher Education}

Exploration and reforms have been done in the past years and the Chinese government has made great achievements in developing higher education. And its efforts and exploration in internationalizing higher education cannot be neglected.

\subsubsection{Understanding "Internationalization"}

The globalization or internationalization of higher education has played a very important role in the development of it. Although the two terms of "globalization" and "internationalization" are often used interchangeably, one can find the differences between them through efforts. Globalization refers to the impact of global changes that cannot be easily fended off by national governments. (Chan, 2004, p. 33) Scott shared the view that internationalization reflects a world order dominated by nation states. (2000, p. 4) Parlo Singh also described that globalization is not a predetermined force that pushes and molds local contexts into uniform shapes (2004, p. 103). Chan (2004, p. 33) further explained the relationship between globalization and internationalization as:

Internationalization, to a certain extent, is a response to the impact of globalization. Internationalization recognizes national boundaries and the uniqueness of individual societies and cultures and in the face of the forces of globalization, urges international understanding and cooperation. 
As to globalization, China has been overwhelmed by the influence of foreign countries. After the founding of P.R. China in 1949, the influence from the Soviet Union penetrated into every field with no exception of higher education. Ever since 1978, western models have been introduced into China's higher education. And after the entry into the WTO, China has participated in global activities in economy, politics, culture, and education as well.

\subsubsection{Causes behind China's Internationalization of Higher Education}

\section{1) Entering into the WTO Giving a Strong Impetus}

In effect, the 1990s saw an initial wave in the field of education, with various reform and development proposals and regulations concerning the ways that China could adopt to integrate its higher education into the world. Then China's entry into the WTO in 2001 ushered in an era when its higher education was internationalized at a staggering speed. The 13th clause of the General Agreement on Trade in Service stated that all training activities, whether funded by the government or individuals should be categorized into the domain of educational services, which included distance education, the establishment of educational institutions overseas, studying abroad and transnational migration of specialists. China's entry into the WTO made new demands on the internationalization of its higher education and offered favorable growth opportunities as well. Now China's higher education developed vigorously and promoted greatly the development of its economy, science and technology in the age of globalization.

\section{2) Understanding Higher Education as an International Enterprise}

With the characteristics of higher education of her own, China's internationalization results from three things. Firstly, to explore the truth and discover knowledge are the fundamental incentive of the development of higher education. The essence of higher education is to create and transfer profound knowledge. As knowledge is borderless, intellectuals in the world have devoted themselves to knowledge expansion and mutual understanding between nations. Education in nature focuses on the whole world, not on one part of it. Secondly, in correspondence with pursuing truth and discovering knowledge, the characteristic of higher education in fostering people determines the internationalization and commonality of higher education. Higher education is different from fundamental education in that it passes on knowledge of specialty, cultivates creative and competent capitals. People with this kind of competence should have international insight, sensibility in following the development trends in science and thinking, world-level ability of research and exploitation, and capability of international understanding and communication. Lastly, the internationalization, to certain extent, is a response to the impacts of globalization and collaboration between educational providers and it is therefore one of the most effective means to gain visibility, increase market share and sustain the competitiveness. (Chan, 2004, p. 32)

\subsubsection{China's Internationalization of Higher Education and the Progress}

China has made great achievements concerning its internationalization of higher education, which may be reflected from the following aspects. (1) Sending students abroad and attracting foreign students to China. According to statistics, over 170,000 students, government-funded or self-supported, went abroad to pursue further study from 1978 to the end of 1991, and China experienced a dramatic increase in the number of its overseas students in the coming years. The figure amounted to 339,700 in 2011 with most of the students funded by themselves or their families. At the same time, many foreign students came to China. (2) Exchanging teachers and experts worldwide. According to the statistics released in 1994, more than 140 Chinese specialists and educators had been dispatched to over 30 countries or regions since China began to reform and open up to the outside world, while up to 13,000 foreign scholars were employed, whether staying for a long or short period, including 1,090 language specialists, 10,200 specialists in other fields and 1600 teachers who came from over 50 countries or regions such as America, Britain, Japan and Germany. (3) Expanding academic exchanges and scientific research cooperation. From 1978 to 1984, 413 Chinese educational delegations with a total of 2506 scholars were sent abroad at the invitation of educational departments in foreign countries, while the number of foreign educational delegations invited by China was estimated at 557 composed of 3090 educators. From 1985 to 1986 , the number of Chinese education delegations sent abroad was 182 consisting of 1110 members and that of foreign delegations coming to China was 213 with 1029 members. Besides, academic exchanges and scientific research cooperation are conducted in the form of holding and attending international academic conferences. (4) Encouraging Chinese-foreign joint programs of running schools, and so forth. According to the statistics, by the end of 1995 the number of Sino-foreign educational institutions reached 300, including 60 in Shanghai and 40 in Beijing City, Jiangsu Province and Guangdong Province each. The foreign partners were predominantly from over 20 developed countries or regions, with America, Australia, Japan and Canada on the top of the list. 


\section{Conclusion}

As has been stated, China's higher education is by nature susceptible to changes, some of the changes being politically-driven, some economically-driven. In the first several years after the founding of the P.R. China, the government's top priorities were given to speeding up the economic construction and to consolidating the newly-established power. For that purpose they wanted to build many poly-technical universities and independent colleges by restructuring the old higher education system. Many poly-technical universities and colleges were built and many more appeared in the inland of the country, while some first rate universities in the country were considerably weakened with a lot of well-known professors and scientists transferred to other universities and the disciplines of liberal education were ignored. What's more, the independent thinking and innovative ideas of the faculty members were seldom, if not no more found later because they had been brainwashed and had their links cut off to their former universities or productive soil. (Shen, 2008, p. 77) By giving workers, peasants and soldiers who were poorly educated access to higher education the Chinese government showed that they were fighting for equality but, as scholars said, giving many young workers, peasants and soldiers admission to universities without giving them entry tests or follow-up term tests, the Chinese government made the higher education a laughing-butt in the history of the world education. (Lu, 2012, p. 53) Thanks to Mr. Deng Xiaoping's reforms, China's higher education, owing to new policies implemented in the past three decades, has turned itself into what it should be, gearing with the needs of the country and contributing to the international cooperation and common pursuit of knowledge.

\section{References}

Chan, W. W. Y. (2004). International Cooperation in Higher Education: Theory and Practice. Journal of Studies in International Education, 8(1), 32-55. http://dx.doi.org/10.1177/1028315303254429

Deng, Xiaoping. (1978). Speech Delivered at National Conference on Education. People's Education, 1(Supplement), 3-7.

Duan, X. R. (2003). Chinese Higher Education Enters a New Era. Academe, 89(6), 22-27. http://dx.doi.org/10.2307/40252555

Hai, T., \& Xiao, W. (2010). Appearing of the Workers, Peasants and Soldiers as College Students for the First Time. Inheritance \& Innovation, 16, 32-33.

Hu, S. M., \& Seifman, E. (Eds). (1987). Education and Socialist Modernization: A Documentary History of Education in the People's Republic of China, 1977-1986. New York: N.Y, AMS Press.

Jiao, J., \& Li, B. (2000). Gains and Losses Resulting from the Restructuring of Universities and Independent Colleges in the First Several Years after the Founding of the People's Republic of China. Academic Forum of Nan $\mathrm{Du}, 20(2), 99-101$.

Jin, Z. (2005). Looking into the Job-hunting of the College Graduates against the Background of the Expansion of University Enrolment. Research in Teaching, 28(4), 313-316.

Li, Q. (2002). Commenting on the Restructuring of Universities and Independent Colleges in the First Several Years after the Founding of the People's Republic of China. Party Literature, 6, 71-77.

Li, Q., \& Shen, H. (2003). On Reinforcing the Merger of Universities and Independent Colleges-A Study of the Merger of Universities and Independent Colleges and of Problems and Solutions. Journal of China Three Gorges University, 25(1), 18-21.

Lu, X. (2012). A Talk about the College Students Enrolment during the "Cultural Revolution". Memories and Archives, 6, 48-53.

Luo, L. (2008). The Favored Treatment Given to the Children from Workers' and Peasants' Families before 1978. University Education Science, 2, 106-110.

Qu, H. (2005). Problems in the Merger of the Country's Universities and Independent Colleges and the Solutions. Journal of Guangdong College of Young Cadres, 59, 152-154.

Shen, D. (2008). The Restructuring That Destroyed the Higher Education System of the Republican Time. University Education Science, 5, 73-81.

$\mathrm{Su}$, W. (1989). The Restructuring of Universities and Independent Colleges in the 1950s. China Higher Education Research, 4, 13-23.

Tan, Z. (1985). Some Thoughts on Decision by the Central Committee of the Chinese Communist Party on the Reform of Education. Educational Review, 2, 26-28. 
Wong, Y., \& Lu, H. (2008). An Economic Perspective of the Expansion of the University Enrolment. Journal of Xianyang Normal University, 23(3), 110-112.

Wu, C. (2001). A Talk about the Restructuring of Universities and Independent Colleges Soon after the Founding of the People's Republic of China. China Higher Education Research, 4, 81-82.

Zhang, Y. (2007). Looking Back Once Again at the Restructuring of Universities and Independent Colleges in the 1950s. Journal of East China Normal University, 25(1), 87-96.

Zhang, Y. (2011). Leighton Stuart and Yenching University. Beijing Observation, 12, 60-62.

\section{Notes}

Note 1. Figures listed above are adapted from Lives of Modern Chinese Scientists, Beijing: Science Publishing House, 1991-1994.

Note 2. Figures From 1998 to 2011 are adapted from the annual National Educational Development Statistical Bulletin issued by the Ministry of Education. (http://www.moe.gov.cn/publicfiles/business/htmlfiles/moe/moe_633/201208/141305.html) 